\title{
AFTER CAPITALISM, DEMOCRATIC MANAGERIALISM
}

\author{
Depois do capitalismo, o gerencialismo democrático \\ Después del capitalismo, el gerencialismo democrático
}

Luiz Carlos Bresser-Pereira'1 | bresserpereira@gmail.com | ORCID: 0000-0001-8679-0557

${ }^{1}$ Fundação Getulio Vargas, Escola de Administração de Empresas de São Paulo, São Paulo, SP, Brazil

\begin{abstract}
Since the late 1970s, capitalism has experienced a regressive stage - neoliberal rentier-financier capitalism - and, since 2008 , it has entered a terminal crisis. Capitalists have ceased to control the process of capital accumulation and innovation that used to legitimize them, and capitalism has stopped producing economic development and human progress. In its place, a new social organization is emerging that the author calls "democratic managerialism", in which the class of managers or technobureaucrats has regained strength and come to constitute the nucleus of the new dominant class coalition. At the same time, democracy has been facing authoritarian challenges well and it is possible to predict that it will deepen into democratic managerialism.
\end{abstract}

KEYWORDS | Capitalism, neoliberalism, managerialism, democracy, human progress.

\section{RESUMO}

A partir do final dos anos 1970, o capitalismo experimentou uma fase regressiva - o capitalismo neoliberal financeirorentista - e, desde 2008, entrou em crise terminal. Os capitalistas deixaram de controlar o processo de acumulação de capital e inovação que os legitimava, e o capitalismo deixou de produzir desenvolvimento econômico e progresso humano. Em seu lugar, está surgindo uma nova organização social, que o autor denomina "gerencialismo democrático", no qual a classe dos gerentes ou tecnoburocratas voltou a se fortalecer e a constituir o núcleo da nova coalisão de classes dominantes. Ao mesmo tempo, a democracia vem enfrentando bem o desafio autoritário, e é possível prever que ela se aprofundará no gerencialismo democrático.

PALAVRAS-CHAVE / Capitalismo, neoliberalismo, gerencialismo, democracia, progresso humano.

\section{RESUMEN}

Desde finales de la década de 1970, el capitalismo experimentó una fase regresiva - capitalismo neoliberal financierorentista - e, desde 2008, ha entrado en una crisis terminal. Los capitalistas dejaron de controlar el proceso de acumulación de capital e innovación que los legitimaba, y el capitalismo dejó de producir desarrollo económico y progreso humano. En su lugar, está emergiendo una nueva organización social que el autor denomina "gerencialismo democrático", en la que la clase de gerentes o tecnoburocratas nuevamente se fortaleció y constituyó el núcleo de la nueva coalición de clases dominante. Al mismo tiempo, la democracia ha enfrentado bien los desafíos autoritarios y es posible predecir que se profundizará en el gerencialismo democrático.

PALABRAS CLAVE I Capitalismo, neoliberalismo, gerencialismo, democracia, progreso humano. 
Sixty years ago, in May 1961, RAE's first issue was launched. Two years earlier, I had been hired, through a competition process, by Fundação Getulio Vargas's Sao Paulo School of Business Administration (Escola de Administração de Empresas de São Paulo da Fundação Getulio Vargas [FGV EAESP]) and then written my first paper. It was an assignment that the members of a mission from Michigan State University gave to new faculty who were going to the United States for their MBA. My paper, written in English, The Rise of the Middle Class and Middle Management in Brazil (Bresser-Pereira, 1962), was my first venture into the issue of the emerging managerial or technobureaucrat class, and was also an analysis of socialist revolutions' distortion towards statism. My essay should have been published in RAE's first issue, but its first editor, my dear late colleague Raimar Richers, was too emphatic about the scientific method and thought my work "lacked sufficient empirical basis". We were in March 1960, I was about to leave to the United States; when I got there, I submitted it to the Journal of InterAmerican Studies, which published it without requiring any changes. The issue of the emergence of a third class in capitalism was widely discussed at the time and had its big moment with James K. Galbraith's (1968) book, The New Industrial State, where he argued about the emergence of the "technostructure".

The 18 months I spent in the United States were of intensive studies. I was then so impressed by that country's development - not only economic but also political development. The United States were then the richest and most powerful country in the world, and the standard of living of all classes did not cease to increase; they were a white, cohesive society that was beginning to firmly confront racism and the Apartheid system; not only were they the model of economy, but also the model of democracy for the world. My wife Vera Bresser-Pereira and I had the opportunity to watch on TV the famous early presidential debates in which John Kennedy and Richard Nixon faced each other; both were brilliant politicians who, in their debate, agreed on everything, showing how integrated the American society was at the time.

Today's picture is a very different one. The United States are still the most powerful country in the economic and military spheres, but it is losing its hegemony to China. It is a country stuck in an inefficient economic liberalism that, since 1980, has been the main cause of very low growth rates, a huge increase in inequality and stagnation in the living standards of its poorer half. It is a society that has lost cohesion, has ceased to share beliefs and goals. It has a political system where democracy has deteriorated and is no longer a model for anyone, in a plutocracy that elects politicians with no real popular support and which has opened the opportunity for right-wing populist politicians to become presidents - an unimaginable thing 60 years ago.

What happened in this while and brought the United States to this decadence? The new historical fact that brought the great country and, along with it, a good part of rich capitalism to crisis in the last 12 years was the Neoliberal Turn that took place in the United Kingdom and the United States around 1980, with the election of Margaret Thatcher and Ronald Reagan to the leadership of both countries. It was a wrong choice from the economic point of view; the United States, which have always been a developmentalist country (though its politicians had a liberal discourse), which kept high customs duties until 1939 (the industrial policy that defines a regime of developmentalist economic policy), suddenly changed the course radically to adopt an economic liberalism that is incompatible with its own economic development. It was a wrong choice in the social sphere as it entailed increased inequality, and in the political sphere as it meant the change of republicanism for an individualistic political liberalism.

While political liberalism sees freedom just as the individual's right to do as he pleases provided it is not against the law, republicanism sees it as a goal to be achieved by society and as a duty of its political leaders to defend the public interest even if it counters their own interests. That was the view of public affairs that guided 
the founding fathers at the time of their independence. They combined in a dialectical manner two opposing ideologies, i.e., republicanism and liberalism. J. G. A. Pocock (1975) demonstrated this in his definitive 1975 book, The Machiavellian Moment. Such republicanism was still strong in the 1960 s United States and it moderated liberalism. I give only two examples related to President John Kennedy: his famous line "Ask not what your country can do for you - ask what you can do for your country" - and the book he published five years before he was elected president, when he was a senator, Profiles on Courage, in which he chose eight senators to tell their stories, basing his choice on the sole criterion that each of them, at some point in their political life, had the greatness to adopt the policy they deemed in line with the interests of the American nation, though the political forces that elected them opposed it. With the neoliberal turn, republicanism was forgotten and the American society was put at the mercy of an inefficient economic liberalism and a reactionary political individualism.

\section{STAGES OF CAPITALISM}

To understand capitalism, I divide it into four stages according to their dominant class: Merchants' Capitalism, Entrepreneurs' Capitalism, Managers' Capitalism and Rentiers-financiers' Capitalism. For this periodical division, I take into account Great Britain and France, the two countries that experienced all four stages.

The first stage, Merchants' Capitalism, covers from the 16th to the mid-18th centuries and marks the transition from feudalism to capitalism. In this stage, the Capitalist Revolution - the formation of the nationstate and the industrial revolution in both countries - took place. The second stage, Entrepreneurs' Capitalism, took place between the early 19th century, when the Industrial Revolution ended in England and France, and the 1929 crisis, which demoralized economic liberalism; it was the capitalism that Adam Smith and Marx analyzed, the former saluting its emergence and emphasizing the market's role in its coordination, the latter defining it as a mode of production based on capital accumulation with incorporation of technical progress, and criticizing it.

Still in this stage, in the late 19th century, the Second Industrial Revolution, which I call the Organizational Revolution, takes place in the United States and begins the third stage - i.e., Managers' Capitalism. Private managers emerge in large private-sector companies and, combined with an also increasing public bureaucracy, form a new class of managers or the technobureaucratic class. Managers thus begin to replace entrepreneurs in running companies. It is the stage where the United States are the hegemonic power, and capitalism ceases to be liberal to become developmentalist or Keynesian - it comes to imply a moderate intervention in the economy by the State. It also becomes social democratic, since in this stage we have the Welfare state, especially in Europe. It was, finally, the stage in which capitalism experienced its great moment - the Golden Years of Capitalism - a period of strong growth, financial stability and decrease in inequalities.

Despite these good results and the important fact that the managerial class was far from having exhausted the contributions it could give to economic growth, a moderate economic crisis, in the 1970s, involving a drop in the profit rate and the emergence of stagflation in the United States, enabled the neoliberal turn. Hence we have Rentiers-financiers' Capitalism or Neoliberal Capitalism, in which entrepreneurs are replaced by rentiers, now in the ownership of large companies. Capitalism returns to economic liberalism as "financiers" rise to power and, speaking on behalf of rentiers, set up a war not only against public bureaucracy, but also against the private managerial class. Private-sector senior executives could not be expelled from the coalition of classes because they ran the large companies, but they became stockholders' favorite adversaries. And financiers are also managers, 
usually with an MBA or even a PhD in Economy, who took the lead in managing financiers' wealth and began to play the role of organic intellectuals of neoliberal financier-rentier capitalism.

In order to legitimize economic liberalism, these financiers resorted to neoclassic economic theory - an economic theory that, since the neoliberal turn, regained dominance in universities and purports to provide "scientific" foundations for neoliberal ideology. This stage, by excluding the State and trying to make the market the only economic coordination institution in capitalism, will be characterized by low growth, high financial instability and a brutal increase in inequality. For this reason, unsurprisingly, it ends early, with the great 2008 financial crisis. Since then, economic liberalism is increasingly demoralized; rich economies grow very slowly, central banks issue money to reduce the interest rate which becomes negative, characterizing a "secular stagnation", and also to fund public spending during the COVID-19 pandemic, without raising demand and inflation. Since Donald Trump's election in the United States and the Brexit referendum in the United Kingdom, both events taking place in 2016, right-wing populism emerged as an irrational reaction to neoliberalism's failure, particularly its inability to tackle the problem of unemployment caused by the failed competition with China. Because the previous three stages were always "progressive", in the sense that they led capitalism to advance in terms of economic, social and political development, and because rentiers-financiers' neoliberal capitalism was a period of serious regression, perhaps it is better not to consider this a true stage of capitalist development, but a mere reactionary deviation.

\section{A human construction}

In the book I am writing, Rentiers-financier's Capitalism and After, I criticize left-wing analysts who cannot distinguish neoliberalism from capitalism and who reject any idea of progress in capitalism, criticize it and foresee its imminent collapse - see, for example, Dardot e Laval (2009). A similar mistake is to say that neoliberalism is "the true face" of capitalism and that the Golden Years would have been an exception. That is, for example, the argument used by Wolfgang Streeck (2011) when he claims that "it is not the trente glorieuses but the series of crises which followed that represents the normal condition of democratic capitalism" (pp. 5-6). That vision would make sense if we understood capitalism as a "natural" phenomenon, rather than the result of a social construction; if we believed that humans were but puppets in a historical process where human will and action are absent. That is a mistaken naturalization of history. It ignores that capitalism is a form of society regulated by two main institutions - the State and the market - which, like all institutions, were built by humans. One may say this construction is, in part, "unconscious". Indeed, Marx and Engels, with historical materialism and the concept of ideology, gave an important contribution to the understanding of human societies and their development. But even in their time, and certainly even more today, humans have had political goals they incorporated into institutions - particularly in the greatest of them, the State.

The modern State is the constitutional-legal system and the organization endowed with coercive power that sustains it; it is the nation's main collective action instrument. At least since the three revolutions that founded the modern State - the Glorious Revolution, the American Revolution and the French Revolution - the modern State is the institution that emerges with capitalism to define and ensure the fulfilling of the final political goals (safety, individual freedom, improvement in living standards, social justice and environmental protection), as well as the instrumental goals (an autonomous and democratic nation-state) that modern societies have defined for themselves since the $18^{\text {th }}$ century. Capitalism was the first mode of production to experience economic development and "human progress", which I define as the historical process through which each nation advances in realizing 
those goals. Thus, capitalism, today, is not a natural form of society, but a social organization formally oriented towards realizing those political goals, it is the first mode of production in which there has been economic development and some human progress. A limited and unsatisfactory progress, but one that cannot be ignored.

The nation-states that exist today are, therefore, the result of the nation's collective action to create a better political society. In this process, individuals and organizations defend their own interests as if they were the interests of all, and, consequently, nations many times experience historical regressions. After all, however, the dialectical vector not only of class interests and political agreements, but also of republican and solidary principles, which equally guide human action, results in human progress.

The previous section of this article is a summary of the first chapter of the book I am writing, Rentiersfinancier's Capitalism and After, in which I discuss the economic and political regression that neoliberal capitalism has represented since 1980 , and show that, since 2008 , it faces a terminal crisis. I then wonder what is to be expected next, and my answer, in the last chapter, is optimistic. I propose that a new form of social organization is emerging which I call "democratic managerialism". Before I started writing the book, I was a critic of those who said capitalism was dying; what is dying, I replied, is neoliberal capitalism. However, I revised this position when I convinced myself that the capitalist class and capitalism had exhausted their ability to promote economic development and, more broadly, human progress and, eventually, I saw hints arising which indicate the emergence of a new form of social organization subsequent to capitalism which I call "democratic managerialism". This social formation is not a stage of capitalism, but a new mode of production that develops when the bourgeoisie is replaced by the capital accumulation process' professional class. The dominant class will now be the public and private managerial class. In the new coalition of classes, the capitalist class will have a secondary role as the control of capital accumulation is being transferred faster each day from capitalists to the managers of large private-sector companies, while the economic policy decision-making that boosts or prevents this accumulation goes to the hands of professional politicians and public servants.

From this point, I summarize the last chapter of the book. I argue that the democratic managerialism that is emerging will be managerialist because the leadership in the investment process has moved from the capitalist to the managerial class; it will be democratic because democracy was a historical achievement of the working and middle classes in the most advanced capitalist countries at the turn of the $20^{\text {th }}$ century, and became a political regime that has consolidated in these countries. When threatened, as it has been for 40 years by neoliberalism, which is authoritarian, and more recently by right-wing populism, it shows strength and resistance, and thus grows stronger.* Not only is democracy not dying, it is thriving and will define the new social organization. Democratic managerialism is unlikely to be as progressive in this first stage as the Golden Years of Capitalism were, because the problem of competition in developing countries has not been solved and continues to pressure wages in the richest countries. But, since I foresee that it will be developmentalist, it may lead the more advanced countries to resume growth and increase their living standards.

\section{Republican, social and developmentalist democracy}

When Marx analyzed capitalism, the new capitalist class shared power and privilege with the decadent aristocracy. For him, this would be the first and the last stage of capitalist development, because soon the decline in the

* I proposed this argument in the essay published by Lua Nova in 2020, Não é a democracia que está morrendo. É o neoliberalismo que fracassou. [It Is Not Democracy That Is Dying. It Is Neoliberalism That Has Failed.] (Bresser-Pereira, 2020). 
profit rate would determine economic collapse, while a socialist revolution would mark the end of capitalism. Instead, what happened at the turn of the $20^{\text {th }}$ century was the Organizational Revolution, which originated the first managerial class, and, with universal suffrage, the Democratic Revolution, which gave some power to the people to defend their interests. He also did not foresee that, once the Industrial and Capitalist Revolution had been carried out by each country, this would bring about sustained economic development, increased living standards and change in the strategic factor of production from capital to technical and organizational knowledge

The logic of emergence of a new social organization is linked, today, on the one hand, to the demand of modern societies for human progress and, on the other, to the fact that the advance of democracy has been making the people heard to a greater extent. Capitalism became the dominant form of organization in all modern societies when it proved more capable of generating wealth and increasing living standards than feudalism and slavery and, later, capable of adapting to the emergence of democracy. But it has always been a mode of production marked by inequality. Now, after the 1980 neoliberal turn and the 2008 crisis, when economic inequality is hitting all-time highs, capitalism cannot seem to be able to generate a satisfactory growth rate, let alone reverse the neoliberal income concentration process, and it shows little capability to control climate change. It is thus becoming evident that capitalism has exhausted its ability to promote human progress. On the other hand, capitalist elites have lost control of capital accumulation. Third, the working and middle classes' outrage at the poor economic results increases conflicts and political polarization more each day. Fourth, it is not clear to political actors what the way out will be, but hints begin to emerge of how the social organization will be which will be born from this generalized crisis.

Capitalism is a dynamic mode of production in which a coalition of classes dominated by the capitalist class runs the process of economic development. Today, however, the capitalist entrepreneurs who still exist have lost economic and political power. The solution to this difficulty, which I have been discussing with myself for some time now, is a postcapitalist solution. I have argued in the book that we could only foresee the end of capitalism if an alternative were to arise. Democratic managerialism should be that alternative. It should be a managerial social formation because the managerial class will be the dominant class; democratic because a certain type of manager, the democratically elected professional politician, will have their legitimacy and political power expanded.

The democracy that initially resulted from the Democratic Revolution was a minimal democracy (guarantee of the Rule of Law, civil rights and universal suffrage), but, since then, democracy also spread into middle-income countries, and the quality of democracy tended to improve. In this political and economic development, democracy became a universal value, not only a form of government but also a progressive ideology.

Today, democracy is the only political regime that possesses social legitimacy. It is instrumental for achieving the political goals that modern societies have set for themselves. In the early 20 th century, the first form of democracy was elite democracy or liberal democracy; after World War II, especially in Europe, democracy became republican, social and developmentalist; it became republican because a significant number of citizens and politicians began to act civically rather than liberally, because they prioritized the public interest rather than their own particular interests as assumed by liberal individualism; it became social because, in addition to civil and political rights, social rights came to be considered, and the welfare State emerged; it became developmentalist rather than liberal because it saw in the State's moderate intervention in the economy an instrument for economic development and human progress, rather than seeing the State as a mere warrantor of property and contracts. Although the transition to a participatory democracy moves slowly in the most advanced democratic countries 
such as Denmark and Switzerland, my forecast is that democracy will continue to progress because the pressure by the working and middle classes for more political participation will continue to deepen.

In recent years, as neoliberal capitalism was drawing to an end, it produced the right-wing populism expressed, in 2016, in Donald Trump's election in the United States and in the Brexit referendum in Great Britain. The reaction of society and of democratic institutions to this threat has shown that democracy is a definitive achievement of humanity.

\section{New historical facts behind democratic managerialism}

What are the new historical facts behind the emergence of democratic managerialism? I propose four, of which the failure of neoliberal capitalism is the first and most obvious one. The other three are the rentier class' inability to rule; the rise of the professional class whose potentials had not yet been exhausted when, in 1980, the neoliberal turn evicted them from the ruling coalition; and the strengthening of democracy, which, under the threat of neoliberalism and, more recently, right-wing populism, shows it is the main political achievement of the working and middle classes.

Poverty or the lack of governance capability on the part of the rentier-financier classes is our second new historical fact. In the three previous stages of capitalist development (the mercantilist, industrial and managerial stages), Marx's prediction that the holders of capital would keep control of society once the country became totally capitalist was confirmed. In all three stages, the capitalists (merchants, entrepreneurs and managers) were not mere privileged profiteers; they played a leadership role in the production process. They were not simply rich people becoming richer and richer. They were also a kind of delegates of society in charge of leading the process of capital accumulation and innovation on which economic growth depends. It was their fundamental role in capitalist development that justified and sustained their power and wealth. That is not the case with rentiers, who either are idle recipients of incomes passively associated with financiers or are also financial speculators. They have no justification for their power and earnings, but because they are the holders of capital, they continue to be the dominant class. This, however, is not a sustainable condition, and it is one of the explanations for why neoliberal rentiers-financiers' capitalism was short-lived - it thrived for 28 years only. It is an essential argument behind my assertion that, in the new form of social organization that is growing, the holders of capital will not be the dominant class. While capitalism was entrepreneurs' capitalism, capitalists were central to the development process; it lost part of its functionality when, in managers' capitalism, the managers replaced the entrepreneurs in managing private-sector companies; it lost all support when idle rentier capitalists replaced the entrepreneurs in the ownership of large companies. Rentiers and financiers are not committed to economic development. They are an idle capitalist class interested in short-term dividends, interests and real estate rent, and not in the long-term expansion of large companies. The exception is the third members of the neoliberal class coalition - the senior executives who run private-sector companies. But in the new social organization, from its early stage, they will have the central role in the capital accumulation process: in neoliberal capitalism, their actions are permanently hindered by rentiers and financiers.

This poverty of coalition of rentiers-financiers is critical because ruling modern societies is an extremely difficult task. If economic liberalism produced growth, ruling nation-states would be a relatively simple task. All governments would have to do is to guarantee social order and keep the fiscal account balanced; the market 
would take care of the rest. But we know that this "invisible hand" does not exist. Adam Smith's "invisible hand" metaphor only makes sense when we are not talking about the whole economic system, only about the competitive sectors in the economy. The markets are unable to coordinate the non-competitive sectors in the economy, the five macroeconomic prices, external current account, income distribution, as well as basic education and health care; these sectors should be coordinated by the state, despite the deficiencies involved. The neoliberal claim that the State's failures are worse than those of the market does not apply, not because these sectors involve market failures, but because the market is relatively absent, and it makes more sense to put them under public management. Neoliberals reject this argument because they expect from the market much more than it can do. They expect the market to coordinate sectors where there is no competition or the existing competition is essentially biased, as with the five macroeconomic prices. Ruling nation-states, contributing for human progress and world peace are the noblest actions that humans are called on to take. Ruling is a very difficult task that requires experienced and competent politicians, ideally endowed with republican virtues; politicians who continuously reaffirm the nation's main values and beliefs and are able to reinterpret them whenever new historical facts so require. Few politicians have these qualities. They may be progressive or conservative, liberal or developmentalists, but they should be republican and politically competent.

Our third new historical fact behind the rise of democratic managerialism is the fact that the managerial class had not exhausted all of its potentials when the neoliberal turn reduced their political power. The rise of a narrow liberal financier-rentier class coalition interrupted the managerial class' secular emergence, but that interruption was not and could not be definitive. While, in the neoliberal stage, capitalist entrepreneurs lost centrality, two managerial groups remained associated to rentiers - financiers and large company senior executives. Now, in the emerging democratic managerialism, the professional class will have the opportunity to lead the whole system. Not only the private managerial class, but also the public one and, within it, professional politicians.

Finally, the fourth new historical fact that explains democratic managerialism is democracy's resilience, in that it has survived and thrived for the last 40 years, when it was attacked by neoliberalism, which is intrinsically meritocratic and authoritarian, and, more recently, by authoritarian right-wing populism. While liberalism is a capitalist ideology that was born with the emergence of nation-states and national markets, democracy is an ideology and a form of government founded on the working and middle classes, which the bourgeoisie and liberalism rejected for a long time with the argument that democracy would be the "tyranny of the majority". The bourgeoisie and liberalism were pro the rule of law and civil rights, which are a condition for democracy, but a minimally defined democracy is only reached when these rights are accompanied by the basic political right universal suffrage. Democracy was a popular achievement that was only accepted by the bourgeoisie after a long political struggle by socialist parties and middle-class intellectuals pro universal suffrage. Nearly the entire 19th century was necessary before the capitalist class could feel relatively assured that the victory of socialist parties in general elections would not lead to their expropriation and the implementation of socialism. It accepted democracy, but built a broad system of "safeguards" - laws that established strict constitutional limits to democracy: a clear division of powers and the need for a qualified majority to change the Constitution. And practical limits to the right of the people: the possibility of funding politicians in elections, or simply bribing them, the control of media and the subordination of unions to strict laws.

Later, even the dominant classes in modern capitalism - the capitalist class and the managerial class came to view democracy as their favorite regime, firstly because both social classes are large, diverse classes whose members need rules to regulate their ambitions and reach political power. Secondly, because authoritarian 
governments are usually subordinate to the capitalist class, but may be simply arbitrary governments who ignore not only the rights of the people, but also those of the elites.

\section{Market society without a dominant capitalist class}

Democratic managerialism assumes a market society without a dominant capitalist class; it assumes a social formation where we will continue to have private property of the means of production, profits and wages are the two main revenues, and the state and the market coordinate the economic system. We cannot, however, call this social formation capitalist because the capitalist class has lost control of the capital accumulation and innovation process. Some will say it is impossible to think of a society where capital and market are present, but the capitalist class ceased to be the dominant class; or where the previous dominant class lost power, but the new social formation continues to mistakenly bear its name. There is, however, a historical precedent for this type of situation. The aristocracy gradually lost its military power over the long period in which the bourgeoisie emerged. In this historical process, we arrived at mercantilism, which was already the first stage of capitalism but continued to be seen as a stage of the ancien régime - the aristocratic regime of absolute monarchies. Now, after about 100 years of rise of the managerial class, in which the bourgeoisie gradually lost control of the capital accumulation process, it is hard for us to see the emergence of a new social organization. In the most developed societies, which are the main object of this study, the rise of the managerial class regains momentum, the bourgeoisie remains rich, but it has lost is main role to senior executives and elected and non-elected public servants.

At the same time, we can see democracy growing stronger as it has resisted the attack of authoritarian neoliberals and is now repelling the attack of right-wing populism. In this scenario, the people and the more educated portions of the middle class are gaining political influence and may seize this opportunity to advance democracy, on the one hand, by making it representative of popular demands, and, on the other, by making parliament less dependent on rentiers' and financiers' interests, and its members more committed to an economic policy of responsible development.

\section{CONCLUSION}

Democratic managerialism will keep many characteristics of capitalism - profits and capital accumulation, wage labor, market coordination of competitive industries. The fundamental difference is that the economic coordination of the economy will be carried out not according to the logic of economic liberalism, which has failed, but according to the logic of developmentalism, which is the obvious alternative to that liberalism. It is thus assumed that the managerial class of private managers and public servants will have the strategic role of leading the capital accumulation and innovation process and, therefore, the task of ruling. Professional politicians will define the necessary economic reforms and public policies as representatives of the people, with greater responsibility and autonomy in relation to the rich. They will represent the various sectors of society, including the capitalist sectors, but they will not represent mainly the capitalist class. These politicians will work on a series of institutional reforms which will make their candidacies more independent from funding by capitalists and rich managers.

Paul Mason (2013) says that the seeds of postcapitalism are beginning to bear fruits. "Capitalism, it turns out, will not be abolished by forced-march techniques. It will be abolished by creating something more dynamic that 
exists, at first, almost unseen within the old system, but which breaks through, reshaping the economy around new values, behaviors and norms." We can see, in modern societies, indications that point to the new. Mason believes they point to the "rise of collaborative production: goods, services and organizations are appearing that no longer respond to the dictates of the market and the managerial hierarchy". Yes, the new is emerging from the clues left by the present and the recent past. But one should not be so optimistic as to believe that the information revolution is producing a "new man". Human behavior will continue to be simply the dialectical vector of survival instincts and human coexistence. Societies are not only the result of self-interest or survival instinct, but also of the need of each of us to share life in society with others. After 40 years of neoliberalism and individualism, changes in individual and group behavior towards a simpler, more collaborative way of life are necessary; they are a response to the threat of climate change and increasing inequality. The information revolution has created a network society, but not a better society - a society where the amount of information has increased chaotically; where the elites have lost the monopoly of organized information that the control of mainstream media used to ensure. It has created space for new, progressive ideas, but also for conspiracy theories and fake news produced by the extreme right wing.

My view is that, in the new context produced by the information revolution, the new that is embodied by democratic managerialism will supplant the old that is present in neoliberalism, in right-wing populism and in conspiracy theories. The change is taking place not towards an ideal society, but towards a society within our reach, where power passes from rentier capitalists to managers, and political power, mainly, to professional politicians. As democracy advances, ordinary people increase their say, even though not by much. My main argument in that direction was that capitalists' power grew thinner as they lost they strategic role in controlling the capital accumulation and innovation process. Today, the manager leads most of capital accumulation and innovation within large companies. Within the capitalist class, only young entrepreneurs retain an important role: leading startups which are today the main source of radical innovation. But that is the only thing that warrants capitalism some legitimacy and keeps it alive; the other things are just remains, starting with wealth without a social role.

The failure of neoliberal financier-rentier capitalism was a new evidence of how wrong neoliberalism was in assuming that the markets are able to exclusively coordinate the economic system, and it has created space for the return of a developmentalist policy regime. This change is beginning to happen. After the 2008 financial crisis, the threat posed by right-wing populism and the COVID-19 pandemic, we can see the main countries moving towards developmentalism. Angela Merkel's Germany, the European Union and, finally, president Joe Biden's United States are not only adopting countercyclical fiscal packages, but also starting to define and implement policies that promote reindustrialization. The expectation in a 1985 book by Evans Rueschemeyer and Skocpol (1985) is becoming reality, the State is once again being called on to promote economic development. At the time the book was published, they were not heard, but history led reality and necessity to prevail over a reactionary ideology. The new social organization has not produced miracles, what lies ahead is by no means a utopia. I make an optimistic prediction, but I suppose it to be realistic. I am just predicting that we are taking a step towards a more reasonable and balanced way of coordinating the economy and ruling nation-states.

\section{NOTE}

Emeritus Professor, Fundação Getulio Vargas, Escola de Administração de Empresas de São Paulo. 


\section{REFERENCES}

Bresser-Pereira, L. C. (1962). The rise of middle class and middle management in Brazil. Journal of Inter-American Studies, 4(3), 313-326. doi: 10.2307/164949.

Bresser-Pereira, L. C. (2020). A democracia não está morrendo. Foi o neoliberalismo que fracassou. Lua Nova - Revista de Cultura e Política, 111: 51-79. doi: 10.1590/0102-051079/111

Dardot, P., \& Laval, C. (2009). La mouvelle raison du monde: Essai sur la société néolibérale, Paris, France: La Découverte/Poche.

Evans, P. B., Rueschemeyer, D., \& Skocpcol, T. (Eds.). (1985). Bringing the state back. Cambridge: Cambridge University Press.
Galbraith, J. K. (1968). O novo estado industrial. Rio de Janeiro, RJ: Civilização Brasileira. Original em inglês, 1967.

Mason, Paul (2013) PostCapitalism - A Guide to Our Future", London: Penguin Books.

Pocock, J. G. A. (1975). The machiavellian moment. Princeton: Princeton University Press.

Streeck, W. (2011, Sept./Oct.). The crisis of democratic capitalism. New Left Review, 71, 5-30. Retrieved from https:// newleftreview.org/ll/71/wolfgang-streeck-the-crises-ofdemocratic-capitalism

\section{AUTHOR'S CONTRIBUTION}

Luiz Carlos Bresser-Pereira was the sole author of the theoretical construction, of its application to the reality of contemporary capitalism, and of the writing of this article. There was no special data survey. Cecilia Heise reviewed the article. 